Akreditasi KEMENRISTEKDIKTI, Nomor: 148/M/KPT/2020
http://iurnal.stkippersada.ac.id/jurnal/index.php/VOX

\title{
PENGEMBANGAN BAHAN AJAR KOMIK DIGITAL PADA MATERI GERAK
}

\author{
Azizul $^{1}$, Widya Yuliatin Riski ${ }^{2}$, Devi Indah Fitriyani ${ }^{3}$, Ira Nofita Sari ${ }^{4}$ \\ ${ }^{1,2,3,4}$ Fakultas Pendidikan MIPA dan Teknologi, IKIP PGRI Pontianak \\ Email: azizulijul31@gmail.com ${ }^{1}$, widya.ever88@gmail.com ${ }^{2}$, deviindahfitriyani01@gmail.com ${ }^{3}$, \\ iranofitasari87@gmail.com ${ }^{4}$
}

INFO ARTIKEL
Riwayat Artikel:
Menerima $: 03$ September 2020
Revisi $\quad: 16$ Oktober 2020
Diterima $: 18$ Nopember 2020

\section{Kata Kunci:}

Pengembangan, Bahan Ajar, Komik Digital, Gerak

\section{Keywords:}

Development, Teaching

Materials, Digital Comics,

Motion

\section{Korespondensi:}

\section{Azizul}

Fakultas Pendidikan MIPA dan Teknologi, IKIP PGRI Pontianak Email:

azizulijul31@gmail.com

\begin{tabular}{l} 
ABSTRAK \\
\hline Perkembangan teknologi digital dewasa ini telah terjadi secara masif tidak \\
terkecuali di dunia pendidikan Mengingat pesatnya perkembangan teknologi \\
digital maka penelitian ini berupa pengembangan bahan ajar komik digital pada \\
materi gerak. Tujuan penelitian ini adalah untuk mengembangkan bahan ajar \\
komik digital pada materi gerak sebagai pendukung dalam pembelajaran. \\
Metode yang digunakan dalam penelitian ini adalah metode penelitian dan \\
pengembangan (research and development). Rancangan penelitian yang akan \\
digunakan dalam penelitian ini mengikuti 5 langkah atau tahapan penelitian dan \\
pengembangan menurut Borg \& Gall. Pada penelitian ini tahapan \\
pengembangan yang dilakukan sampai pada tahap main product revision. \\
Pertimbangan tersebut dilakukan karena keterbatasan waktu dan biaya. Teknik \\
pengumpulan data yang digunakan dalam penelitian ini adalah teknik \\
komunikasi tidak langsung dengan alat pengumpul data yaitu lembar validasi \\
ahli materi dan media dengan skala Likert. Data yang akan diperoleh dalam \\
penelitian pengembangan, selanjutnya akan diolah dan dianalisis sesuai dengan \\
masalah dan tujuan yang telah dirumuskan. Data dari lembar yang berupa data \\
kuantitatif dianalisis secara deskriptif untuk mencari persentase dari kelayakan \\
bahan ajar pada materi gerak berbasis komik digital berdasarkan penilaian ahli. \\
Berdasarkan penelitian yang telah dilakukan, diketahui bahwa telah dihasilkan \\
bahan ajar komik digital pada materi gerak. Kualitas pengembangan bahan ajar \\
komik digital pada materi gerak berkategori layak menurut ahli materi dengan \\
rata-rata persentase sebesar 76,89 dan menurut ahli media sangat layak dengan \\
persentase sebesar $89,17 \%$.
\end{tabular}
ABSTRACT

The development of digital technology today has occurred massively, including in the world of education. Given the rapid development of digital technology, this research is in the form of developing digital comic teaching materials on motion material. The purpose of this research is to develop digital comic teaching materials on motion materials as a support in learning. The method used in this research is the method of research and development (research and development). The research design that will be used in this study follows 5 steps or stages of research and development according to Borg \& Gall. In this research, the development stage is carried out until the main product revision stage. This consideration was made due to time and cost limitations. The data collection technique used in this research is indirect communication techniques with data collection tools, namely material and media expert validation sheets with a Likert scale. The data to be obtained in development research will then be processed and analyzed in accordance with the problems and objectives that have been formulated. Data from the sheet in the form of quantitative data were analyzed descriptively to find the percentage of the feasibility of teaching materials on digital comic-based motion material based on expert judgment. Based on the research that has been done, it is known that digital comic teaching materials have been produced on motion material. The quality of the development of digital comic teaching materials on motion material is categorized as feasible according to material experts with an average percentage of 76.89 and according to media experts it is very feasible with a percentage of $89.17 \%$. 


\section{PENDAHULUAN}

Perkembangan teknologi digital dewasa ini telah terjadi secara masif tidak terkecuali di dunia pendidikan. Pesatnya Ekspansi teknologi digital terus-menerus menuntut keterampilan dan pengetahuan baru untuk mengimbangi perkembangan tersebut. Demikian halnya tantangan pembelajaran kemudian muncul dan mendorong para pendidik menyajikan pembelajaran yang inovatif dan selaras dengan perkembangan teknologi yang dapat mendorong peserta didik untuk tidak tergantung pada pendidik.

Ketergantungan peserta didik pada pendidik dapat diatasi dengan memberikan bahan ajar kepada peserta didik sehingga peserta didik dapat mempelajari sendiri materi yang akan disampaikan oleh pendidik. Bahan ajar memiliki fungsi strategis bagi proses belajar mengajar. Bahan ajar dapat membantu peserta didik dan pendidik dalam kegiatan pembelajaran, sehingga pendidik tidak terlalu banyak menyajikan materi. Disamping itu, bahan ajar dapat menggantikan sebagian peran guru dan mendukung pembelajaran individual. Hal ini akan memberi dampak positif bagi pendidik, karena sebagian waktunya dapat dicurahkan untuk membimbing belajar peserta didik. Dampak positifnya adalah dapat mengurangi ketergantungan pada pendidik dan membiasakan belajar mandiri (Wahyuni, 2016).

Diantara sumber pembelajaran yang sekarang sedang dikembangkan di berbagai lembaga pendidikan adalah pembelajaran berbasis Information and Communication
Technology (ICT). Upaya implementasi pembelajaran berbasis ICT tentu memerlukan persiapan-persiapan yang baik dan yang paling utama ialah tersedianya materi ajar dalam bentuk e-book yang memenuhi syarat untuk diupload dalam e-learning.

Fisk (2017) menjelaskan bahwa pembelajaran untuk peserta didik tidak hanya keterampilan dan pengetahuan tetapi untuk mengidentifikasi sumber untuk mempelajari keterampilan dan pengetahuan. Belajar akan lebih penting untuk mengetahui mengapa peserta didik membutuhkan suatu pengetahuan atau keterampilan, dan kemudian di mana menemukan sumber belajar yang efisien daripada menjejalkan materi ajar kepala siswa.

Mata pelajaran IPA Terpadu merupakan mata pelajaran yang ditempuh perserta didik saat berada di Sekolah Menengah Pertama. Materi yang dipelajari yaitu salah satunya dalam bidang fisika dan salah satu materi yang didapat ialah materi gerak. Menurut puspendik kemendikbud diketahui bahwa pada materi gerak (mekanika) memiliki nilai rata-rata hasil Ujian Nasional 42,94 dan nilai tersebut masih tergolong rendah. Penelitian yang telah dilakukan oleh Sutrisno (2018) menjelaskan rendahnya hasil belajar fisika dikarenakan kurangnya media pembelajaran yang bisa memotivasi peserta didik, kurangnya minat baca, dan peserta didik cendrung bosan dengan buku pelajaran yang ada.

Penelitian ini akan mengembangkan bahan ajar yang bersifat multi bahannya yaitu komik pembelajaran fisika. Wurwiarwin (2018) menjelaskan komik fisika kontekstual berbasis 
digital dapat memudahkan siswa untuk belajar fisika. Menurut Anesia, dkk. (2018) diketahui bahwa pengembangan media pembelajaran berbasis digital pada materi gerak lurus dapat digunakan sebagai media alternatif dari berbagai kesulitan yang dihadapi siswa dalam memahami sebuah materi pembelajaran Fisika. Terkait hal dimaksud, maka inovasi pembelajaran yang dilakukan sudah tentu harus mendukung pembelajaran yang terintegrsi dengan teknologi dalam hal ini yaitu teknologi digital. Mengingat pesatnya perkembangan teknologi digital maka penelitian ini berupa pengembangan bahan ajar komik digital pada materi gerak.

\section{METODE PENELITIAN}

Metode penelitian yang digunakan dalam penelitian ini adalah metode penelitian dan pengembangan (research and development). Produk yang dikembangkan dalam penelitian ini adalah bahan ajar pada materi gerak berbasis komik digital. Rancangan penelitian yang akan digunakan dalam penelitian ini mengikuti 5 langkah atau tahapan penelitian dan pengembangan menurut Borg \& Gall. Langkah-langkah diikuti sampai menghasilkan produk yang berupa bahan ajar materi gerak berbasis komik digital. Adapun langkahlangkah tersebut dapat dilihat pada Gambar 1. Pada penelitian ini tahapan pengembangan yang dilakukan sampai pada tahap main product revision. Pertimbangan tersebut dilakukan karena keterbatasan waktu dan biaya.

Variabel dalam penelitian ini yaitu materi gerak dan komik digital. Materi fisika dalam penelitian ini adalah materi gerak. Indikator capaian pada materi ini adalah peserta didik dapat menganalisis Gerak Lurus Beraturan (GLB) dan Gerak Lurus Berubah Beraturan (GLBB), serta gerak melingkar beraturan. Komik digital dalam penelitian ini merupakan media komunikasi visual yang unik dengan menggabungkan teks dan gambar dalam bentuk yang kreatif serta mempunyai kekuatan untuk menyampaikan informasi berupa materi pembelajaran yaitu gerak serta dapat diakses melalui koneksi internet maupun aplikasi android.

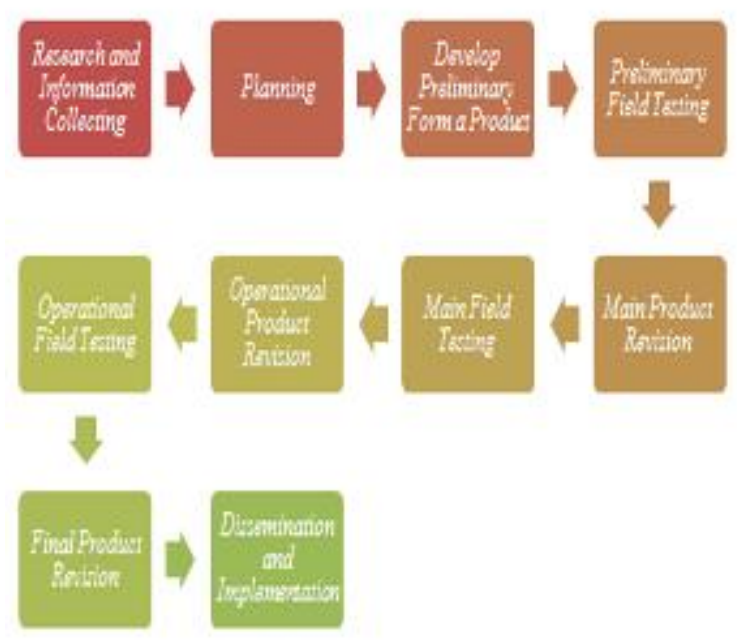

Gambar 1. Langkah-langkah Penelitian dan

Pengembangan Bahan Ajar Materi Gerak Berbasis Komik Digital menurut Borg \& Gall

Waktu penelitain pengembangan dilaksanakan mulai bulan April sampai Juli 2020. Teknik pengumpulan data yang digunakan dalam penelitian ini adalah teknik komunikasi tidak langsung dengan alat pengumpul data yaitu lembar validasi ahli materi dan media dengan skala Likert.

Data yang akan diperoleh dalam penelitian pengembangan, selanjutnya akan diolah dan dianalisis sesuai dengan masalah dan tujuan 
yang telah dirumuskan. Untuk mengetahui pengembangan bahan ajar komik digital pada materi gerak dengan cara mendeskripsikan bagaimana hasil pengembangan yang dilakukan melalui 5 tahapan menurut Borg \& Gall menggunakan data display yaitu menyajikan produk dari pengembangan modul yang telah dikembangkan. Data dari lembar yang berupa data kuantitatif dianalisis secara deskriptif untuk mencari persentase dari kelayakan bahan ajar pada materi gerak berbasis komik digital berdasarkan penilaian ahli. Kriteria kelayakan bahan ajar pada materi gerak berbasis komik digital akan ditentukan dari persentase dari validator. Adapun kriteria kualitas alat ukur (Muhafid, 2013) disajikan pada Tabel 1.

Tabel 1 Kriteria Persentase Skor Penilaian Kualitas Media Bahan ajar Komik Digital Materi Gerak

\begin{tabular}{ccl}
\hline No. & \multicolumn{1}{c}{ Skor } & \multicolumn{1}{c}{ Kriteria } \\
\hline 1. & $81,25 \%<$ skor $\leq 100 \%$ & Sangat \\
& & Layak \\
2. & $62,50 \%<$ skor $\leq 81,25 \%$ & Layak \\
3. & $43,75 \%<$ skor $\leq 62,50 \%$ & Kurang \\
& & Layak \\
4. & $25,00 \%<$ skor $\leq 43,75 \%$ & Tidak Layak \\
\hline
\end{tabular}

\section{HASIL DAN PEMBAHASAN}

Penelitian ini menghasilkan produk berupa media komik digital pada materi gerak. Pengembangan ini dilakukan dengan model Borg \& Gall sebagai berikut:

1. Research and Information Collecting (Mengumpulkan Potensi dan Masalah)

Analisis masalah dalam penelitian ini dilakukan dengan melakukan kajian terhadap masalah sedang sedang dihadapi dunia pendidikan atau secara khusus masalah yang sedang dihadapi sekolah. Diperoleh informasi bahwa nilai Ujian
Nasional diketahui bahwa nilai rata-rata hasil Ujian Nasional mata pelajaran IPA pada materi gerak (mekanika) 42,94 dan nilai tersebut masih tergolong rendah. Selanjutnya tim peneliti melakukan studi literatur untuk mencari potensi masalah. Menurut Sutrisno (2018) menjelaskan rendahnya hasil belajar fisika dikarenakan kurangnya media pembelajaran yang bisa memotivasi peserta didik, kurangnya minat baca, dan peserta didik cendrung bosan dengan buku pelajaran yang ada. Prihanto dan Yunianta (2018) menyatakan bahwa kurangnya peran guru dalam memanfaatkan media pembelajaran adalah salah satu faktor rendahnya nilai siswa. Salah satu alternatif inovasi untuk mengatasi permasalahan minat siswa untuk belajar IPA adalah dengan memperbaiki sistem pembelajaran IPA menggunakan media berupa bahan ajar yang dapat diterima siswa (Febriyandika, dkk., 2016). Menurut Poedjiadi (dalam Matsun, 2018) pembelajaran adalah proses interaksi yang dilakukan oleh pendidik dan peserta didik baik di dalam maupun di luar kelas dengan menggunakan media dan berbagai sumber belajar sebagai bahan kajian. Dipertegas lagi perubahan dunia kini tengah memasuki era revolusi industri 4.0 atau revolusi industri dunia keempat dimana teknologi informasi telah menjadi basis dalam kehidupan manusia (Kemristekdikti, 2018a).

Berdasarkan paparan tersebut, dapat diketahui bahwa diperlukan pengembangan media pembelajaran yang sesuai dengan siswa untuk mengatasi rendahnya hasil belajar siswa dalam era digital.

2. Planning (Merencanakan) 
Berdasarkan masalah yang sedang dihadapi, maka dilakukan pengembangan bahan ajar komik digital pada materi gerak. Pengembangan yang dilakukan dengan menyusun desain produk sesuai dengan aspekaspek yang memang diperlukan dalam mengembangkan sebuah bahan ajar. Aspekaspek yang diperhatikan meliputi aspek materi gerak dan media komik digital.

Bahan ajar berupa komik merupakan jenis media pembelajaran cetak yang dirancang untuk dapat dipelajari secara mandiri oleh peserta didik menjadi alternatif dalam suatu pembelajaran. Komik digital ini dirancang untuk mebelajarkan siswa terkait konsep gerak. Selain itu, melalui komik digital ini diharapkan peserta didik dapat termotivasi dalam belajar IPA secara mandiri dan menyenangkan, sehingga hasil belajar peserta didik dapat meningkat. Oleh karena itu, komik yang dirancang merupakan komik digital dengan tampilan yang menarik yang dapat diinstall di smartphone peserta didik, sehingga peserta didik dapat belajar dimanapun dan sesuai dengan trend saat ini yang semuanya serba digital.

\section{Develop Preliminary Form a Product} (Desain Produk)

Produk berupa bahan ajar komik digital pada materi gerak. Desain produk berupa bahan ajar komik digital pada materi gerak dengan memperhatikan aspek materi dan media. Pada aspek materi hal-hal yang diperhatikan meliputi isi, keterbahasaan, dan keterlaksanaan. Sedangkan untuk aspek media, hal-hal yang diperhatikn yaitu anatomi komik, media gambar, dan tampilan.
Desain produk pada aspek materi dilakukan dengan memperhatikan kesesuain isi komik dengan kompetensi dasar dan indikator pada materi gerak. Kompetensi Dasar pada materi gerak yaitu memahami gerak lurus, dan pengaruh gaya terhadap gerak berdasarkan Hukum Newton, serta penerapannya pada gerak makhluk hidup dan gerak benda dalam kehidupan sehari-hari., sedangkan indikator pada materi gerak yaitu Indikator capaian pada materi ini adalah peserta didik dapat menganalisis Gerak Lurus Beraturan (GLB) dan Gerak Lurus Berubah Beraturan (GLBB), serta gerak melingkar beraturan. Selain memperhatikan dilakukan dengan memperhatikan kesesuain isi komik dengan kompetensi dasar dan indikator, ada hal lain yang juga diperhatikan yaitu, Ketepatan konsep materi, kejelasan topik pembelajaran, keruntutan materi, cakupan materi, ketuntasan materi, ketepatan dialog/teks dengan. Aspek keterbahasaan meliputi pemilihan kata dalam penjabaran materi, penggunaan kata yang komunikatif, kesesuaian jalan cerita dengan taraf berpikir peserta didik, kemudahan mmemahami alur, dan penggunaan kata yang tidak menimbulkan penafsiran ganda. Sedangkan untuk aspek keterlaksanaan, hal-hal yang diperhatikan adalah dukungan media bagi kemandirian belajar siswa dan kemampuanmedia menambah pengetahuan siswa.

Desain produk pada aspek media dilakukan dengan memperhatikan anatomi komik, media gambar yang digunakan, dan tampilan. Desain produk berupa bahan ajar 
komik digital pada materi gerak dapat dilihat pada Gambar 2.
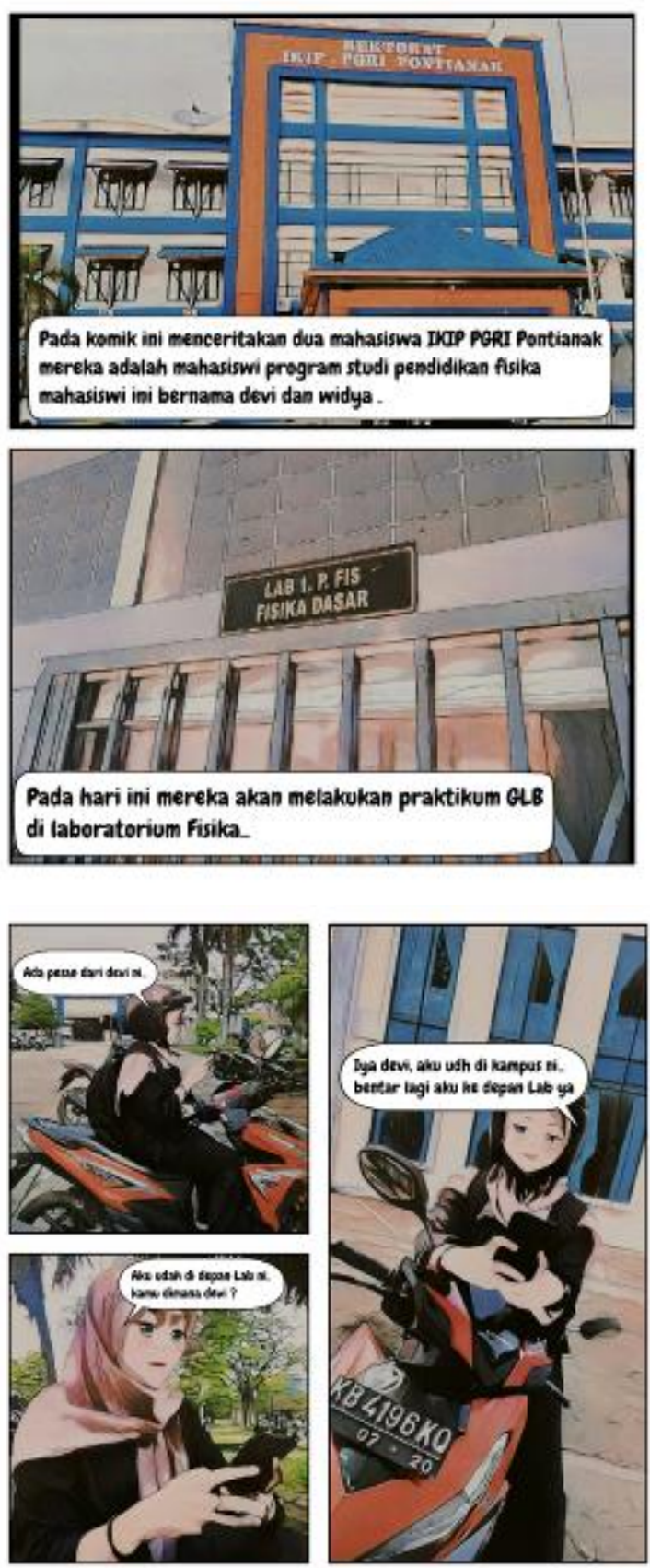
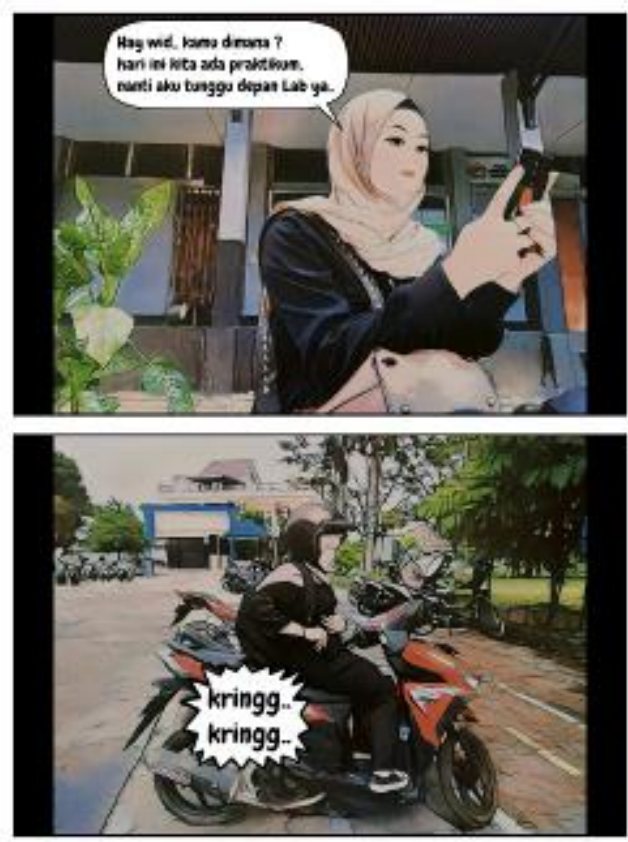

Gambar 2. Desain Bahan Ajar Komik Digital pada Materi Gerak

\section{Preliminary Field Testing (Validasi \\ Desain)}

Validasi desain produk berupa Bahan Ajar Komik Digital pada Materi Gerak dilakukan oleh ahli materi dan ahli media yang masingmasing berjumlah tiga orang. Ahli materi dan ahli media terdiri dari dosen Program Studi Pendidikan Fisika, Guru IPA SMP dan pelaku di bidang seni (komikus). Validasi desain produk yang dikembangkan dapat dilihat pada Tabel 2.

Berdasarkan Tabel 2 diketahui bahwa hasil penilaian menurut ahli materi dinyatakan layak dengan rata-rata persentase sebesar 76,89\% dan sangat layak menurut ahli media dengan persentase sebesar $89,17 \%$. Oleh karena itu Bahan Ajar Komik Digital pada Materi Gerak dikatakan dapat digunakan dalam pembelajaran. 
Tabel 2. Penilaian menurut Ahli Materi dan Media terhadap Bahan Ajar Komik Digital pada Materi Gerak

\begin{tabular}{|c|c|c|c|}
\hline \multicolumn{4}{|c|}{ Validasi Ahli Materi } \\
\hline Validator & $\begin{array}{c}\text { Validator } \\
1\end{array}$ & $\begin{array}{c}\text { Validator } \\
2\end{array}$ & $\begin{array}{c}\text { Validator } \\
3\end{array}$ \\
\hline $\begin{array}{c}\text { Rata-rata } \\
\text { menurut } \\
\text { validator }\end{array}$ & $77,78 \%$ & $77,78 \%$ & $73,61 \%$ \\
\hline $\begin{array}{c}\text { Rata-rata } \\
\text { keseluruhan } \\
\text { validator }\end{array}$ & \multicolumn{3}{|c|}{$76,39 \%$} \\
\hline \multicolumn{3}{|c|}{ Validasi Ahli Media } \\
\hline $\begin{array}{c}\text { Validator } \\
\text { Validator } \\
\text { Rata-rata } \\
\begin{array}{c}\text { menurut } \\
\text { validator }\end{array}\end{array}$ Validator & Validator \\
\hline $\begin{array}{c}\text { Rata-rata } \\
\text { keseluruhan } \\
\text { validator }\end{array}$ & $85,00 \%$ & $85,00 \%$ \\
\hline
\end{tabular}

\section{Main Product Revision (Perbaikan} Desain)

Perbaikan desain produk berupa Bahan Ajar Komik Digital pada Materi Gerak berdasarkan masukan dari ahli materi dan ahli media sebagai validator. Komentar dan saran dari validator dapat dilihat pada Tabel 3.

Tabel 3. Komentar dan Saran dari Validator terkait Modul Praktikum IPA Berbasis Inkuiri Menurut Ahli Materi

\begin{tabular}{|c|c|c|}
\hline No. & $\begin{array}{l}\text { Aspek yang } \\
\text { Dinilai }\end{array}$ & Komentar dan Saran \\
\hline 1. & $\begin{array}{l}\text { Kesesuaian isi } \\
\text { komik dengan } \\
\text { Kompetensi } \\
\text { Dasar (KD) } \\
\text { dan indikator }\end{array}$ & $\begin{array}{l}\text { Indikator pembelajaran } \\
\text { yang dicapai } \\
\text { disesuaikan dengan isi } \\
\text { komik. Indikator yang } \\
\text { harus dicapai oleh } \\
\text { peserta didik } \\
\text { dipersempit untuk media } \\
\text { komik. }\end{array}$ \\
\hline 2. & $\begin{array}{l}\text { Keruntutan } \\
\text { materi }\end{array}$ & \begin{tabular}{lcr} 
Materi & yang & disajikan \\
sesuai & \multicolumn{2}{c}{ keruntutan } \\
konsep & yang & harus \\
dicapai & oleh & peserta \\
didik & &
\end{tabular} \\
\hline 3. & $\begin{array}{l}\text { Kemampuan } \\
\text { media }\end{array}$ & $\begin{array}{l}\text { Berikan pengetahuan } \\
\text { baru bagi peserta didik }\end{array}$ \\
\hline
\end{tabular}

\begin{tabular}{lll}
\hline $\begin{array}{l}\text { menambah } \\
\text { pengetahuan } \\
\text { siswa }\end{array}$ & $\begin{array}{l}\text { terkait materi gerak, } \\
\text { misalnya percobaan di } \\
\text { laboratorium. }\end{array}$ \\
\hline 4. Sampul & $\begin{array}{l}\text { Sampul komik memuat } \\
\text { judul yang menarik tapi } \\
\text { sesuai konsep yangingin } \\
\text { disampaikan. }\end{array}$ \\
\hline 5. Karakter tokoh & $\begin{array}{l}\text { Tokoh yang ditampilkan } \\
\text { menggunakan karakter } \\
\text { yang unik agar menarik. }\end{array}$ \\
\hline
\end{tabular}

Berdasarkan tabel dan penjelasan di atas, jadi sangat memungkinkan sekali bahwa pengembangan bahan ajar komik digital pada materi gerak dikembangkan atau digunakan pada setiap sekolah menengah pertama guna memberikan pengalaman belajar kepada siswa yang lebih bermakna. Dengan adanya media pembelajaran berbasis digital di sekolah guru dan siswa diharapkan mampu memahami kecanggihan perkembangan teknologi yang disedia oleh sekolah. Karena perkembangan teknologi memberi kesempatan bagi para pendidik dalam memecahkan serta mengkaji ulang masalah-masalah pendidikan yang ada (Yuberti, 2015). Penggunaan internet telah banyak membantu dalam kehidupan manusia, mulai dari berita nasional/internasional, hiburan, jejaring sosial, bahkan dunia pendidikan.

\section{SIMPULAN}

Berdasarkan penelitian yang telah dilakukan, diketahui bahwa telah dihasilkan bahan ajar komik digital pada materi gerak. Kualitas pengembangan bahan ajar komik digital pada materi gerak dapat digunakan dalam pembelajaran IPA. Hasil penilaian menurut ahli materi dinyatakan layak dengan rata-rata persentase sebesar $76,89 \%$ dan sangat 
layak menurut ahli media dengan persentase sebesar $89,17 \%$.

\section{DAFTAR RUJUKAN}

Erlina. 2016. "Inovasi Pembelajaran melalui Penelitian dan Pengembangan Bahan Ajar". Jurnal Al Bayan: Jurnal Jurusan Pendidikan Bahasa Arab. 8(1).

Etkina, Eugenia; Murthy, Sahana.; and Zou, Xuely. 2006. "Using Introductory Labs to Engage Students in Experimental Design". American Journal of Physics.74 (11): 979-986.

Febriandika, Triyan; Wahyuni, Sri; dan Lesmono, Albertus Djoko. 2016. "Pengembangan Modul IPA dengan Teknik Komik Disertai Kartu Soal di SMP". Prosiding Seminar Pendidikan Nasional Pendidikan 2016. 1: 295-306.

Fisk, Peter. 2017. The Future Of Learning Will Be Dramatically Different, In School And Throughout Life (https://www.thegeniusworks.com/2017 /01/future-education-young-everyonetaught-together/).

Matsun; Ramadhan, Dochi; Lestari, Isnania. 2018. "Perancangan Media Pembelajaran Listrik Magnet Berbasis Android di Program Studi Pendidikan Fisika IKIP PGRI Pontianak". Jurnal Pendidikan Informatika dan Sains. 7(1), 107-117.

Nurcahyo, dkk, 2016. Belajar Praktis Seni Budaya SMP/MTs Kelas VIII Semester 2. Klaten: Viva Pakarindo.

Pramana, Takari Chandra. 2015. "Pengembangan Media Komik sebagai Bahan Ajar IPA Materi Hubungan Sumber Daya Alam dengan Lingkungan pada Siswa Kelas IV SD Negeri Pendowoharjo Sleman (Online)". Jurnal Universitas PGRI Yogyakarta.

Prihanto, Dhita Agoes dan Yunianta, Tri Nova Hasti. 2018. Pengembangan Media Komik Matematika pada Materi Pecahan untuk Siswa Kelas V Sekolah Dasar. Jurnal MAJU, 5(1): 79-90.

Sutrisno Tri. 2018. Pengembangan Komik IPA Fisika sebagai Media Pembelajaran peserta Didik Pokok Bahasan Gerak. Repository UIN Raden Intan Lampung.

Wahyuni, Sri. 2016. "Pengembangan Bahan Ajar IPA Berbasis Komik pada Pokok Bahasan Gerak di SMP". Prosiding Seminar Nasional Pendidikan. 1: 564572.

Werdiana I Komang, dkk. 2018. "Pengembangan Komik Fisika Kontesktual Berbasis Android Pokok Bahasan Tekanan untuk Sekolah Menengah Pertama". (JPF) Jurnal Pendidikan Fisika. 2: 287-238. 